\title{
Demographics and Psychological Factors Associated with Adiposity in Nurses
}

\author{
Bernarda Sánchez-Jiménez ${ }^{1}$ (i), Reyna Sámano ${ }^{2}$ (i), Daniela Chinchilla-Ochoa ${ }^{3}$, \\ Rosa Morales-Hernández ${ }^{2}$ and Ana Rodríguez-Ventura ${ }^{2, * \text { (ID }}$ \\ 1 Sub-Direction of Research in Communitarian Interventions National, Institute of Perinatology, Urales \# 800, \\ Col. Lomas de Virreyes, Delegación Miguel Hidalgo, Mexico City C.P. 11000, Mexico; \\ emiberna20@yahoo.com.mx \\ 2 Department of Nutrition and Bioprogramming, Research Direction, National Institute of Perinatology, \\ Montes Urales \# 800, Col. Lomas de Virreyes, Delegación Miguel Hidalgo, Mexico City C.P. 11000, Mexico; \\ ssmr0119@yahoo.com.mx (R.S.); rmh080868@yahoo.com (R.M.-H.) \\ 3 Departament of Neurosciences, National Institute of Perinatology, Urales \# 800, Col. Lomas de Virreyes, \\ Delegación Miguel Hidalgo, Mexico City C.P.11000, Mexico; danielachinchilla87@gmail.com \\ * Correspondence: rovalilia@hotmail.com; Tel.: +52-5520-9900 (ext. 653)
}

Received: 22 January 2018; Accepted: 10 March 2018; Published: 30 March 2018

\begin{abstract}
Adiposity-based chronic disease (ABCD), overweight-Ow- or obesity-Ob-) in health personnel is as frequent as in the general population, even though they understand well the importance of maintaining a healthy weight. Thus, it is highly likely that certain demographic and psychological conditions, independently of knowledge, are contributing to develop ABCD. The aim of this study was to examine the association between these factors and ABCD in nurses. Data were collected from a cross-sectional study conducted in a tertiary level institute in Mexico City from 2012 to 2013. All the nurses of the institute of any age, shift, service area and seniority were invited to participate and 55\% (265) accepted. We found that ABCD was present in $79.6 \%$, and low self-esteem and emotional distress in $26 \%$ and $10 \%$, respectively. Working in the night shift $(p=0.031)$, labor seniority $\geq 15$ years $(p=0.006)$, having 1 or more children $(p=0.021)$ and sessions of physical activity $<30 \mathrm{~min}(p=0.03)$ were associated with $\mathrm{ABCD}$. Low self-esteem (OR $=2,95 \% \mathrm{CI}$ $1.150-3.07, p=0.023)$ and emotional distress (OR $=4,95 \%$ CI 1.472-13.078, $p=0.012)$ were associated with unhealthy lifestyle (less of 3 days per week and/or less of $30 \mathrm{~min}$ per session of physical activity and poor dietary habits). Therefore, strategies to prevent and treat $A B C D$ must consider each context among nurses and psychological disorders need be identified to avoid an unhealthy lifestyle.
\end{abstract}

Keywords: adiposity; overweight; obesity; nurses; lifestyle; self-esteem; emotional distress

\section{Introduction}

Women are the main health carers in families and most of the nursing staff is still female as a result of the process of sex stereotyping of the roles that tend to be transmitted through the socialization process [1]. Nurses educate, care, advise and investigate, but there are no particular programs to care for their health. Some authors have commented that nurses do not display ideal self-concern about their health because they live a double sense of duty and are affected by their environment and job [2]. Additionally, although they have enough self-care knowledge, they often do not have a correct self-care [3]. Health care employees, including nurses, are at increased risk of non-communicable diseases (NCDs) like diabetes, hypertension and coronary heart diseases [4]. The main risks of NCDs are physical inactivity, poor dietary habits, smoking and alcohol abuse. NCD risk factors such as physical inactivity and adiposity based chronic disease $(A B C D)$ have been widely reported among 
nurses in countries like Australia, United Kingdom, New Zealand and South Africa [2,4-6]. On the other hand, nurses experience high levels of stress/distress due to the nature of their work and workplaces; and their socialization into ways of working that minimizes the likelihood of self-care, so then it is also important to evaluate their self-esteem and emotional distress [7,8]. Given all this evidence, we hypothesized that some demographic conditions, such as age, labor seniority, civil state, shift, etc., as well as psychological disorders may be associated with ABCD among nurses. The aim of this study was to identify the frequency of adiposity in nurses and its association with demographic and psychological conditions, besides lifestyle.

\section{Materials and Methods}

\subsection{Study Design}

Data were collected from a cross-sectional study conducted in 2012-2015. During this period, 478 nurses were invited, but only 265 (55\%) accepted to participate. Inclusion criteria were: female gender, any age, any labor seniority, any shift and area of service. An exclusion criterion was male gender. Men nurses also participated to avoid discrimination, but their results were not analyzed for this study. This project was approved by the Research and Ethics Committee of our institution, 212250-08361. Written informed consent was obtained from all participants.

\subsection{Body Mass Index (BMI) and Classification of Overweight (Ow) and Obesity (Ob)}

BMI was calculated as the weight divided by height squared $\left(\mathrm{kg} / \mathrm{m}^{2}\right)$ and $\mathrm{Ow} / \mathrm{Ob}$ were classified according to World Health Organization cut-off points [9]. Ow was defined as BMI $\geq 25$ and $\mathrm{Ob} \geq 30$.

\subsection{Demographic and Lifestyle Factors}

Age, labor seniority, area of service, shift, civil status and number of children were determined by a questionnaire. We also recorded time per session of physical activity, sessions per week and quality of food through an internal validated questionnaire.

\subsection{Metabolic Disturbs}

Hyperglycemia was considered if fasting glucose was $\geq 100 \mathrm{mg} / \mathrm{dL}$ [10]. Metabolic syndrome was defined according the National Cholesterol Education Program-Third Adult Treatment Panel (NCEP-ATPIII) [11] with three or more of the following characteristics: fasting plasma glucose $\geq 100 \mathrm{mg} / \mathrm{dL}$, blood pressure $\geq 130 / \geq 85 \mathrm{mmHg}$, triglycerides $\geq 150 \mathrm{mg} / \mathrm{dL}, \mathrm{HDL}<50 \mathrm{mg} / \mathrm{dL}$ and $/$ or waist $\geq 88 \mathrm{~cm}$.

\subsection{Psychological Evaluation}

Self-esteem is a state which the person assumes herself/himself as a competent person. According to Cooper Smith, self-esteem is self-evaluation and/or self-judgment about his/her values. There is an interaction between the person's self-esteem and ability to understand his/her abilities, in such a way that decreasing self-esteem causes weakness and inability, while increasing self-esteem can revive the feeling of power and value in the person [12]. Emotional distress is defined as the emotional variations that regulate the behavior related to external event, it was measured using Goldberg test, already validated $[13,14]$.

\subsection{Statistical Analysis}

Descriptive statistics was used. $X^{2}$ and Student $t$-test were used for categorical and numerical variables, respectively. A multivariable logistic regression model was performed to derive odds ratios (ORs), 95\% confidence intervals (95\% CIs), and $p$-values. A $p$-value less than 0.05 was considered statistically significant. All statistical analyses were performed using IBM SPSS Statistics version 22 (IBM Inc., Armonk, NY, USA). 


\section{Results}

Mean age was $41.5 \pm 8.1$ years and labor seniority was $18.6 \pm 8.5$ years, $83 \%$ had studies until bachelor or technician level, $64 \%$ worked in intensive care areas. Adiposity was present in $79.6 \%$ : Ow in $43.4 \%$ and $\mathrm{Ob}$ in $36.2 \% ; 68 \%$ had waist circumference $>80 \mathrm{~cm} ; 30 \%>88 \mathrm{~cm} ; 65 \%$ and $78 \%$ had $>0.80$ and $\geq 0.50$ waist/hip index, respectively. The nurses of the night shift had the highest percentage of $\mathrm{ABCD}(87 \%)$ in comparison with nurses of the morning $(80 \%)$ or evening $(67 \%)$ shifts $(p=0.031)$. $\mathrm{ABCD}$ was associated with seniority at work ( $\geq 15$ years) $(p=0.006)$, but not with the age, Table 1.

Table 1. Demographic characteristics in ABCD vs. normal BMI.

\begin{tabular}{|c|c|c|c|c|c|}
\hline & \multicolumn{2}{|c|}{$\begin{array}{c}\text { ABCD } \\
n=211(80)\end{array}$} & \multicolumn{2}{|c|}{$\begin{array}{c}\text { Normal-BMI } \\
n=54(20)\end{array}$} & \multirow[b]{2}{*}{$p^{*}$} \\
\hline & No. & $\%$ & No. & $\%$ & \\
\hline \multicolumn{6}{|l|}{ Age (years) } \\
\hline $23-39$ & 76 & 74 & 27 & 26 & \multirow{3}{*}{0.148} \\
\hline $40-49$ & 102 & 84 & 19 & 16 & \\
\hline$\geq 50$ & 33 & 80 & 8 & 20 & \\
\hline \multicolumn{6}{|l|}{ Education level } \\
\hline Technician & 95 & 83 & 19 & 17 & \multirow{4}{*}{0.288} \\
\hline Specialist & 17 & 77 & 5 & 23 & \\
\hline Bachelor & 91 & 78 & 25 & 22 & \\
\hline Master & 8 & 62 & 5 & 38 & \\
\hline \multicolumn{6}{|l|}{ Seniority } \\
\hline$<15$ years & 51 & 67 & 25 & 33 & \multirow{3}{*}{0.006} \\
\hline $15-29$ years & 142 & 84 & 26 & 16 & \\
\hline$\geq 30$ years & 18 & 86 & 3 & 14 & \\
\hline \multicolumn{6}{|l|}{ Shift } \\
\hline Morning & 116 & 80 & 29 & 20 & \multirow{3}{*}{0.031} \\
\hline Evening & 30 & 67 & 15 & 33 & \\
\hline Night & 65 & 87 & 10 & 13 & \\
\hline \multicolumn{6}{|l|}{ Service area } \\
\hline Intensive care & 131 & 78 & 38 & 22 & \multirow{3}{*}{0.526} \\
\hline Inpatients & 41 & 84 & 8 & 16 & \\
\hline Outpatients or without patients & 39 & 83 & 8 & 17 & \\
\hline \multicolumn{6}{|l|}{ Civil state } \\
\hline With partner & 136 & 82 & 30 & 18 & \multirow{2}{*}{0.526} \\
\hline Without partner & 75 & 76 & 24 & 24 & \\
\hline \multicolumn{6}{|l|}{ Number of children } \\
\hline None & 46 & 70 & 20 & 30 & \multirow{2}{*}{0.021} \\
\hline $1-5$ & 165 & 83 & 24 & 17 & \\
\hline
\end{tabular}

Mean weight was $68.8 \pm 12.1 \mathrm{~kg}$, body mass index (BMI) was $28.6 \pm 4.8 \mathrm{~kg} / \mathrm{m}^{2}$, waist circumference was $84.8 \pm 10 \mathrm{~cm}$, waist/hip index $0.54 \pm 0.06$, systolic blood pressure was $109.4 \pm 7.7$ and diastolic blood pressure was $71.4 \pm 7$. Only one nurse had hypertension, $25 \%$ had metabolic syndrome, $67.5 \%$ had abnormal fasting glucose. The $45 \%$ and $41 \%$ had hypercholesterolemia and hypertriglyceridemia, respectively. Hyperglycemia $(p=0.05)$, hypercholesterolemia $(p=0.026)$ and hypertriglyceridemia $(p \leq 0.001)$ were associated with ABCD (Table 2). 
Table 2. Biochemical characteristics in ABCD vs. normal BMI.

\begin{tabular}{|c|c|c|c|c|c|c|}
\hline & \multicolumn{3}{|c|}{$\mathrm{ABCD}$} & \multicolumn{3}{|c|}{ Normal BMI } \\
\hline & \multicolumn{3}{|c|}{$n=211(80)$} & \multicolumn{3}{|c|}{$n=54(20)$} \\
\hline & No. & $\%$ & No. & $\%$ & $O R *(95 \% \mathrm{CI})$ & $p^{+}$ \\
\hline \multicolumn{7}{|l|}{ Cholesterol } \\
\hline High (>200 mg/dL) & 102 & 48 & 17 & 31 & $2.0(1.1,3.8)$ & \\
\hline Triglycerides & 102 & 84 & 19 & 16 & & 0.026 \\
\hline High (>150 mg/dL) & & & & & & \\
\hline \multicolumn{7}{|l|}{ Glucose } \\
\hline High $(\geq 100 \mathrm{mg} / \mathrm{dL})$ & 99 & 47 & 10 & 19 & $3.9(1.9,8.1)$ & 0.000 \\
\hline Index waist-hip & 149 & 71 & 30 & 56 & $1.9(1.0,3.5)$ & 0.056 \\
\hline High (cardiovascular risk) & 50 & 76 & 27 & 50 & $3.2(1.1,1.6)$ & 0.000 \\
\hline
\end{tabular}

About the lifestyle factors explored, $42 \%$ practiced exercise, but only $3 \%$ followed the international recommendations: $\geq 2.5 \mathrm{~h}$ per week and $\geq 30 \mathrm{~min}$ in each session. Nurses who practiced physical activity less than three days per week, had risk of being $\mathrm{ABCD}(\mathrm{OR}=4.1)$ and less than $30 \mathrm{~min}$ in each session had also risk $(\mathrm{OR}=2)$, Table 3 .

Table 3. Physical activity in ABCD vs. normal BMI.

\begin{tabular}{|c|c|c|c|c|c|c|}
\hline \multirow{3}{*}{ Physical Activity } & \multirow{2}{*}{\multicolumn{3}{|c|}{$\begin{array}{c}\text { ABCD } \\
n=211(80)\end{array}$}} & \multicolumn{3}{|c|}{ Normal BMI } \\
\hline & & & & \multicolumn{3}{|c|}{$n=54(20)$} \\
\hline & No. & $\%$ & No. & $\%$ & OR * $(95 \% \mathrm{CI})$ & $p^{\dagger}$ \\
\hline \multicolumn{7}{|l|}{ Days per week } \\
\hline$<3(n=257)$ & 207 & 98 & 50 & 93 & $4.1(1.0,17.1)$ & 0.095 \\
\hline \multicolumn{7}{|l|}{ Minutes per session } \\
\hline$<30(n=154)$ & 130 & 62 & 24 & 44 & $2.0(1.1,3.7)$ & 0.033 \\
\hline
\end{tabular}

On the other hand, about emotional status, $26 \%$ showed low self-esteem and $10 \%$ emotional distress. These conditions were not associated with $A B C D$, but low self-esteem $(\mathrm{OR}=2,95 \% \mathrm{CI}$ $1.150-3.07, p=0.023)$ and emotional distress $(\mathrm{OR}=4,95 \% \mathrm{CI} 1.472-13.078, p=0.012)$ were associated with unhealthy lifestyle (less of 3 days per week and/or less of 30 min per session of physical activity and poor dietary habits).

\section{Discussion}

These nurses had the highest frequency of $\mathrm{ABCD}(\mathrm{Ow} / \mathrm{Ob})$ compared with other groups of nurses [15,16], and in comparison with the national prevalence in Mexico among women (73\%) [17]. International studies have also reported high frequency of ABCD in nurses 65-76\% [18], hypercholesterolemia in 30\% [19], hyperglycemia in 58\% [20], hypertriglyceridemia in 66\% [21] and metabolic syndrome in 15-33\% [22,23]; percentages slightly lower than our findings with the exception of hypertriglyceridemia and metabolic syndrome that are more frequent in other populations.

We found a higher frequency of Ow and Ob-ABCD- among night shift nurses, such as other authors have also reported over the last 30 years [24-28]. This means that there are still no effective strategies or these are not working for night shift nurses. On the other hand, it is important to identify that seniority at work and being a mother (having one or more children) were also associated to $A B C D$ because nurses whit these conditions should receive more attention in order to prevent and treat $\mathrm{Ow} / \mathrm{Ob}$, since they are principal health careers for the people. Finally, working at home as a mother and outside as a nurse is a double mission that implicates less time for self-care; in fact, there is 
evidence that when mothers work, their children increase in weight [29], but mothers also increase their weight during the limited time they have to practice their self-care and a healthy lifestyle in the family [30].

Physical inactivity is the 4th risk factor [31] for all-cause mortality and our participants do not follow the international recommendations about doing exercise and the sedentary lifestyle is associated with chronic diseases [32]. We also need to consider the influence of urban zone in the sedentary lifestyle because nurses of a rural zone in the north of Mexico do exercise [15] at a higher proportion (63.3\%) than our participants.

We found an association between low self-esteem and emotional distress with unhealthy lifestyle (sedentary and poor dietary habits), as other authors have reported [33] and in this case, despite the fact that $A B C D$ was not associated with these psychological disorders, they may contribute to develop $\mathrm{ABCD}$ after a long time, so we suggest finding causality through a prospective study. On the other hand, in a study where 4980 nurses [34] were invited to participate to answer a survey, only $15.5 \%$ accepted, so then, our rate of participation was higher, however, in that study, 93\% knew that ABCD needs treatment but $76 \%$ did not alert patients. It would be transcendent to achieve success among the nursing staff to prevent and treat $A B C D$ for their own health status and also because they help physicians reinforce health counseling. If we could achieve success among the health staff it is possible we may see better results in the general population to decrease the prevalence of overweight/obesity (ABCD).

\section{Conclusions}

Nurses have a high cardiovascular risk due to the alterations found, so they must be attended immediately. Strategies to prevent ABCD should be directed at all health workers, but specially to nurses with children, seniority, working night shifts and with psychological disorders.

Acknowledgments: Sources of funding for this study were from National Institute of Perinatology, Mexico City, Mexico.

Author Contributions: Bernarda Sanchez-Jimenez, Reyna Sámano, Daniela Chinchilla-Ochoa and Ana Rodriguez-Ventura conceived and designed the study; and Rosa Morales-Hernández executed questionnaires and metabolic studies.

Conflicts of Interest: The authors declare no conflict of interest.

\section{References}

1. Phiri, L.; Draper, C.; Lambert, E.; Kolbe-Alexander, T. Nurses' lifestyle behaviours, health priorities and barriers to living a healthy lifestyle: A qualitative descriptive study. BMC Nurs. 2014, 13, 38. [CrossRef] [PubMed]

2. Skaal, L.; Pengpid, S. Obesity and health problems among South African healthcare workers: Do healthcare workers take care of themselves? S. Afr. Fam. Pract. 2011, 53, 563-567. [CrossRef]

3. Sánchez-Jiménez, B.; Sámano, R.; Chinchill-Ochoa, D.; Rodriguez-Ventura, A. Autocuidado de enfermeras y su asociación con su estado emocional. Salud Pública México 2014, 56, 235-236.

4. World Health Organization: Global Status Report on Noncommunicable Diseases 2010. Available online: http:/ / www.who.int/nmh/publications/ncd_report2010/en/ (accessed on 11 December 2012).

5. Blake, H.; Harrison, C. Health behaviors and attitudes towards being role models. Br. J. Nurs. 2013, 22, 86-94. [CrossRef] [PubMed]

6. Bogossian, F.E.; Hepworth, J.; Leong, G.M.; Flaws, D.F.; Gibbons, K.S.; Benefer, C.A.; Turner, C.T. A cross-sectional analysis of patterns of obesity in a cohort of working nurses and midwives in Australia, New Zealand, and the United Kingdom. Int. J. Nurs. Stud. 2012, 49, 727-738. [CrossRef] [PubMed]

7. Foureur, M.; Besley, K.; Burton, G.; Yu, N.; Crisp, J. Enhancing the resilience of nurses and midwives: Pilot of a mindfulness-based program for increased health, sense of coherence and decreased depression, anxiety and stress. Contemp. Nurse 2013, 45, 114-125. [CrossRef] [PubMed]

8. Bakusic, J.; Schaufeli, W.; Claes, S.; Godderis, L. Stress, burnout and depression: A systematic review on DNA methylation mechanisms. J. Psychosom. Res. 2017, 92, 34-44. [CrossRef] [PubMed] 
9. World Health Organization (WHO). Obesity: Preventing and Managing the Global Epidemic. Report of a WHO Consultation; WHO Technical Report Series No. 894; WHO: Geneva, Switzerland, 2000.

10. Expert Panel on Detection, Evaluation, and Treatment of High Blood Cholesterol in Adults. Executive Summary of Third Report of the National Cholesterol Education Program (NCEP). Expert Panel on Detection, Evaluation, and Treatment of High Blood Cholesterol in Adults (Adult Treatment Panel III). JAMA 2001, 285, 2486-2497.

11. Alberti, K.; Zimmet, P.; Shaw, J. The metabolic syndrome a new worldwide definition. Lancet 2005, 366, 1059-1062. [CrossRef]

12. Salimi, S.; Zare-Farashbandi, F.; Papi, A.; Samouei, R.; Hassanzadeh, A. The effect of group bibliotherapy on the self-esteem of female students living in dormitory. J. Educ. Health Promot. 2014, 3, 89. [PubMed]

13. Fuentelsanz-Gallego, C.; Roca-Roger, M.; Úbeda-Bonel, I.; García-Viñets, L.; Pont-Ribas, A.; López-Pisa, R.; Pedreny-Orial, R. Validation of a questionnaire to evaluate the quality of nonprofessional caregivers of dependent persons. J. Adv. Nurs. 2001, 33, 548-554. [CrossRef]

14. Ferré-Grau, C.; Sevilla-Casado, M.; Boqué-Cavallé, M.; Aparicion-Casals, M.R.; Valdivieso-López, A.; Lleixá-Fortuño, M. Effectiveness of problem solving technique applied by nurses: Decreased anxiety and depression in family caregivers. Aten. Primaria 2012, 44, 695-701. [CrossRef] [PubMed]

15. Trejo, P.M.; Araujo, R.; Orozco, C.; Mollinedo, F.E.; Piña, H.D.; Hernández, F.; Barrios, J.M. Factores de riesgo cardiovascular según la etapa de cambio conductual en personal de enfermería. Rev. Cuidarte 2012, 3, 349-354.

16. Escasany, M.; Tumminello, M.J.; Gonále, G.A. Síndrome metabólico en personal de enfermería. Rev. Esp. Nutr. Diet. 2012, 16, 89-93. [CrossRef]

17. Gutierrez, J.P.; Rivera-Dommarco, J.; Shamah-Levy, T.; Villalpando-Hernandez, S.; Franco, A.; Cuevas-Nasu, L.; Barquera, S.; Campos-Nonato, I.; Hernández Barrera, L.; Pedroza, A.; et al. Encuesta Nacional de Salud y Nutrición 2012. Resultados Nacionales; Instituto Nacional de Salud Publica (MX): Cuernavaca, Mexico, 2012.

18. Blake, H.; Malik, S.; Mo, P.K.H.; Pisano, C. 'Do as I say, but not as I do': Are next generation nurses role models for health? Perspect. Public Health 2011, 131, 231-239. [CrossRef] [PubMed]

19. Chomistek, A.K.; Chiuve, S.E.; Eliassen, A.H.; Mukamal, K.J.; Willett, W.C.; Rimm, E.B. Healthy lifestyle in the primordial prevention of cardiovascular disease among young women. J. Am. Coll. Cardiol. 2015, 6, 43-51. [CrossRef] [PubMed]

20. Mathiew-Quirós, A.; Salinas-Martínez, A.M.; Hernández-Herrera, R.J.; Gallardo-Vela, J.A. Metabolic Syndrome in workers in a second level hospital. Rev. Med. Inst. Mex. Seguro Soc. 2014, 52, 580-587. [PubMed]

21. Palacios-Rodríguez, R.G.; Paulín-Villalpando, P.; López-Carmona, J.M.; Valerio-Acosta Mdel, M.; Cabrera-Gaytán, D.A. Metabolic syndrome in health care personnel from a primary care unit. Rev. Med. Inst. Mex. Seguro Soc. 2010, 48, 297-302. [PubMed]

22. Alam, M.F.; Nasreen, S.; Ullah, E.; Hussain, A. The awareness and prevalence of metabolic syndrome in medical community of Bahawalpur. Oman Med. J. 2011, 26, 26-28. [PubMed]

23. Lira, M.T.; Kunstmann, F.; Caballero, E.; Guarda, E.; Villaroel, L.; Molina, J.C. Prevención cardiovascular y actitud de cambio frente a factores de riesgo: Un análisis crítico del estado actual. Rev. Med. Chile 2006, 134, 223-230. [CrossRef] [PubMed]

24. Gangwisch, J.E.; Rexrode, K.; Forman, P.; Mukamal, F.; Malaspina, D.; Feskanich, D. Daytime sleepiness and risk of coronary heart disease and stroke: Results from the Nurses' Health Study II. Sleep Med. 2014, 15, 782-788. [CrossRef] [PubMed]

25. Niedhammer, I.; Lert, F.; Marne, M.J. Prevalence of overweight and weight gain in relation to night work in a nurses' cohort. Hôpital National de Saint-Maurice, France. Int. J. Obes. Relat. Metab. Disord. 1996, 20, 625-633. [PubMed]

26. Marqueze, E.; Lemos, L.; Soares, N.; Lorenzi-Filho, G.; Moreno, C. Weight gain in relation to night work among nurses. Work 2012, 41, 2043-2048.

27. Pan, A.; Schernhammer, E.; Sun, Q.; Hu, F. Rotating Night Shift Work and Risk of Type 2 Diabetes: Two Prospective Cohort Studies in Women. PLoS Med. 2011, 8, e1001141. [CrossRef] [PubMed]

28. Mitsuhashi, T.; Suzuki, E.; Takao, S.; Doi, H. Maternal working hours and early childhood overweight in Japan: A population-based study. J. Occup. Health 2012, 54, 25-33. [CrossRef] [PubMed] 
29. Speirs, K.E.; Liechty, J.M.; Wu, C.F.; Strong Kids Research Team. Sleep, but not other daily routines, mediates the association between maternal employment and BMI for preschool children. Sleep Med. 2014, 15, 1590-1593. [CrossRef] [PubMed]

30. Haskell, W.L.; Lee, I.M.; Pate, R.P.; Powell, K.E.; Blair, S.N.; Franklin, B.A.; Macera, C.A.; Heath, G.W.; Thompson, P.D.; Bauman, A. Physical activity and public health: Update recommendation for adults from the American College of Sport Medicine and the American Heart Association. Med. Sci. Sport Exerc. 2007, 39, 1423-1434. [CrossRef] [PubMed]

31. Tremblay, M.S.; Colley, R.C.; Saunders, T.J.; Healy, G.N.; Owen, N. Physiological and health implications of a sedentary lifestyle. Appl. Physiol. Nutr. Metab. 2010, 35, 725-740. [CrossRef] [PubMed]

32. Umaña-Machado, A. Relación entre estilos de vida y condición de salud de las (los) profesionales en enfermería, hospital de Guápiles 2005. Enfermería Costa Rica 2007, 28, 5-11.

33. Kouvonen, A.; Vahtera, J.; Oksanen, T.; Pentti, J.; Väänänen, A.; Heponiemi, T.; Salo, P.; Virtanen, M.; Kivimäki, M. Chronic Workplace Stress and Insufficient Physical Activity. Occup. Environ. Med. 2013, 70, 3-8. [CrossRef] [PubMed]

34. Miller, S.K.; Alpert, P.T.; Cross, C.L. Overweight and obesity in nurses, advanced practice nurses, and nurse educators. J. Am. Acad. Nurse Pract. 2008, 20, 259-265. [CrossRef] [PubMed]

(C) 2018 by the authors. Licensee MDPI, Basel, Switzerland. This article is an open access article distributed under the terms and conditions of the Creative Commons Attribution (CC BY) license (http://creativecommons.org/licenses/by/4.0/). 